\title{
ANALISIS DAN OPTIMASI DESAIN JARING PENGAMATAN DEFORMASI DI KOTA SURABAYA
}

\author{
Ira Mutiara Anjasmara ${ }^{1}$, Yan Adrian Sidharta ${ }^{2}$ \\ 1,2Departemen Teknik Geomatika, FTSLK-ITS, Kampus ITS Sukolilo, Surabaya, 60111, Indonesia \\ e-mail: ${ }^{1}$ ira@geodesy.its.ac.id, ${ }^{2}$ adridharta@gmail.com
}

\begin{abstract}
Abstrak
Berdasarkan Provinsi Jawa Timur Dalam Angka tahun 2017, jumlah penduduk di Kota Surabaya menduduki peringkat pertama di Provinsi Jawa Timur. Dengan jumlah penduduk yang besar, dibutuhkan pembangunan kota yang sesuai. Pembangunan ini akan memberikan beban secara fisik terhadap permukaan tanah sehingga menyebabkan deformasi. Adanya deformasi dapat diketahui dengan melakukan pengamatan selama dua atau lebih periode pada beberapa titik di wilayah tersebut. Perencanaan titik pengamatan deformasi harus dibuat sebaik mungkin agar parameter deformasi dapat dihitung secara akurat. Oleh karena itu, optimasi desain jaring pengamatan dibutuhkan. Kegiatan desain dan optimasi dapat diselesaikan melalui perhitungan matematis. Dengan dasar tersebut maka dalam penelitian ini, dilakukan optimasi desain jaring pengamatan deformasi di Kota Surabaya. Hal yang dioptimasi adalah presisi. Selain itu, faktor lain seperti reliabilitas dan biaya menjadi faktor yang harus dikontrol pada proses pembuatan jaring. Dari hasil optimasi jaring, didapatkan desain III sebagai desain yang optimal dibandingkan dengan desain lainnya. Desain III memiliki presisi maksimum pada titik BM16 sebesar $0.605 \mathrm{~mm}$ dan presisi maksimum pada titik BM02 sebesar 1.619 $\mathrm{mm}$. Kekuatan geometri jaring desain III sebesar 0.145. Desain III mampu meminimalisir biaya sebesar $44 \%$ jika dibandingkan terhadap desain jaring dengan maksimum pengamatan.
\end{abstract}

Kata Kunci: Desain Jaring, Optimasi, Metode Analitis, Kualitas Jaring

\begin{abstract}
According to publication on East Java in numbers 2017 the population in Surabaya City was ranked first in East Java Province. With a large population, the development of Surabaya are required. This process will provide an increasing load that may cause deformation. Deformation can be examine by observing for two or more periods at some point in the area. The need of good plan for estimating deformation parameters can be fulfilled by determining a good network. Therefore, it is necessary to establish an observation network carefully. Design and optimization activities can be used through mathematical calculations. With these circumstances, this research aims to optimize design of deformation monitoring network in Surabaya. The optimization process includes precision of the network. In addition, the reliability and cost factor becomes a factor that must be done in the process of making networks. The result from optimization shown that the optimum network is illustrated with design III. This design has a maximum precision at point BM16 with $0.605 \mathrm{~mm}$ and minimum precision at point BM02 with $1.619 \mathrm{~mm}$. The strength of figure of design III is 0.145. Compared with network that include maksimum observation, design III network can reduce the cost for about $44 \%$.
\end{abstract}

Keywords: Network Design, Optimization, Analytical Methode, network quality 


\section{PENDAHULUAN}

Dalam beberapa tahun terakhir GPS telah digunakan sebagai perangkat utama dalam melakukan pengamatan untuk mendapatkan hasil dengan presisi yang tinggi. Untuk mendapatkan presisi yang tinggi dan dengan biaya yang minimum, desain jaring pengamatan GPS tersebut harus dioptimasi agar memenuhi kriteria kualitas yang telah ditentukan (Mehrabi dan Voosoghi 2014). Kriteria kualitas dapat disesuaikan menurut keinginan atau permintaan dari pihak pemberi pekerjaan. Ketentuan kriteria kualitas suatu jaring GPS juga diatur Badan Informasi Geospasial (BIG) dalam Standar Nasional Indonesia tahun 2002 mengenai jaring kontrol horizontal (SNI 2002). Menurut ketentuan tersebut, jaring GPS dikelompokkan kedalam orde-orde mulai dari 00 hingga 4. Pengelompokkan tersebut dibagi berdasarkan fungsi, jarak antar titik, dan ketelitian titik minimal yang harus didapatkan pada pengamatan jaring yang telah didesain. Maka dari itu, optimasi desain jaring menjadi satu hal penting dalam pelaksanaan survei GPS.

Optimasi desain jaring geodetik adalah bagaimana mencari nilai presisi, reliabilitas, dan biaya yang optimal (Kuang 1996). Desain dan optimasi jaring dikategorikan kedalam empat kategori, yakni zero order design (ZOD), first order design (FOD), second order design (SOD), dan third order design (THOD) (Kuang 1996). Pada zero order design (ZOD), datum yang terbaik untuk digunakan pada jaring ditentukan. Dalam first order design (FOD), konfigurasi titik dari jaring yang akan digunakan dioptimasi dengan hasil posisi yang terbaik dari setiap titik. Second order design (SOD) mencari pengamatan terbaik berdasarkan nilai bobot sehingga tidak semua kemungkinan pengamatan dari semua titik dapat digunakan. Third order design (THOD) menambah jumlah pengamatan yang bertujuan untuk meningkatkan jaring yang sudah ada (Khameneh dkk. 2016).

Permasalahan dalam optimasi dapat diselesaikan dengan tiga metode, yakni trial and error, analitis, dan intelligent methods (Mehrabi dan Voosoghi 2014). Metode trial and error dan analitis merupakan metode konvensional sedangkan intelligent methods adalah hasil algoritma dari kedua metode sebelumnya dengan keuntungan dan kerugiannya masing-masing (Kuang 1991). Trial and error memberikan solusi bagaimana kualitas desain yang direncanakan. Ketika kualitas ini tidak sesuai dengan kriteria maka desain tersebut ditolak dan solusi baru dibuat. langkah ini diulang hingga didapatkan desain yang sesuai. Analitis memberikan solusi melalui perhitungan matematis sehingga desain sesuai dengan kriteria (Kaplan dan Ayan 2004).

Dari sudut pandang praktis, dalam pengamatan GPS, titik datum dan titik lain yang akan diukur telah dimonumentasi dalam bentuk benchmark sehingga konsep optimasi second order design (SOD) digunakan untuk mendapatkan hasil pengamatan dengan presisi tinggi. Penggunaan metode trial and error dan analitis dapat digunakan dengan mudah melalui perangkat lunak perhitungan matematis sehingga memudahkan proses optimasi. Penelitian ini bertujuan untuk menerapkan metode optimasi sehingga dapat menghasilkan desain jaring yang optimal sesuai dengan kualitas yang diinginkan. Optimasi menurut second order design (SOD) dengan menggunakan metode analitis diterapkan pada titik-titik pengamatan yang sudah ditentukan.

\section{METODE}

\section{Lokasi Penelitian}

Penelitian ini dilakukan di Kota Surabaya dengan rincian koordinat geografis sebagai berikut: $7^{\circ} 9^{\prime}-7^{\circ}$ $21^{\prime} \mathrm{LS}$ dan $112^{\circ} 36^{\prime}-112^{\circ} 54^{\prime} \mathrm{BT}$.

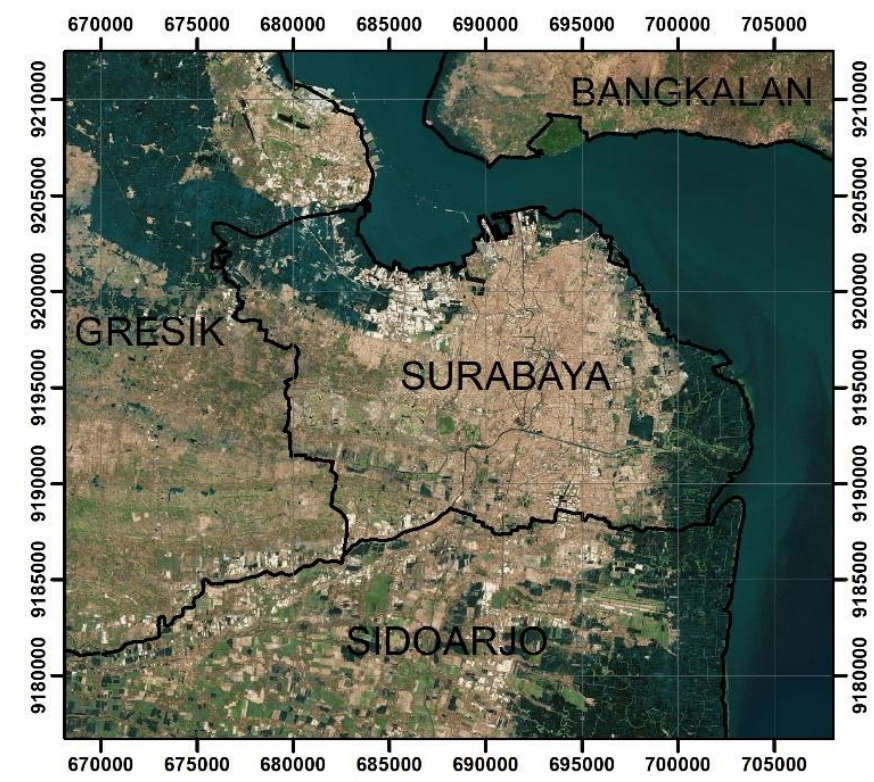

Gambar 1. Kota Surabaya (Google Earth 2018) 


\section{Data}

Data-data yang digunakan dalam penelitian ini adalah:

- Data titik pengamatan deformasi di Kota Surabaya tahun 2018.

- Informasi deformasi yang terjadi di Kota Surabaya.

\section{Pengolahan Data}

Dalam penelitian ini, terdapat beberapa tahapan utama yang harus dilakukan untuk melakukan optimasi desain jaring. Tahap yang pertama adalah pendefinsian titik hingga bentuk matriks yang digunakan. Langkah awal yang perlu dilakukan adalah menentukan titik-titik yang akan digunakan. Data awal yang diperoleh adalah data titik-titik pengamatan di Kota Surabaya dengan jumlah titik sebanyak 21. Data tersebut sudah memiliki nilai koordinat $\mathrm{x}, \mathrm{y}$, dan $\mathrm{z}$ dalam sistem referensi UTM 49 S.

Langkah berikutnya menentukan datum atau disebut constraint pada jaring yang akan dibuat. Constraint dibagi menjadi dua jenis umum, minimum constraint (terkendala minimum) dan inner constraint atau free network adjustment (terkendala bebas). Constraint yang akan dipakai pada jaring adalah minimum constraint, yakni menetapkan paling sedikit satu titik sebagai titik acuan terhadap titik lainnya dimana nilai koordinat titik ini tidak akan berubah bahkan setelah perhitungan (Al zubaidy dkk. 2012). Bentuk matriks minimum constraint $(D)$ dan inner constraint ( $H$ ) adalah (Kaplan dan Ayan 2004)

$$
\begin{aligned}
D & =\left[\begin{array}{lllllllll}
1 & 0 & 0 & 0 & 0 & 0 & 0 & 0 & 0 \\
0 & 1 & 0 & 0 & 0 & 0 & 0 & 0 & 0 \\
0 & 0 & 1 & 0 & 0 & 0 & 0 & 0 & 0
\end{array}\right]_{3 \times 3 * m}^{T} \\
H & =\left[\begin{array}{lllllllll}
1 & 0 & 0 & 1 & 0 & 0 & 1 & 0 & 0 \\
0 & 1 & 0 & 0 & 1 & 0 & 0 & 1 & 0 \\
0 & 0 & 1 & 0 & 0 & 1 & 0 & 0 & 1
\end{array}\right]_{3 \times 3 * m}^{T}
\end{aligned}
$$

kolom matriks $D$ dan $H$ menunjukkan jumlah titik yang digunakan $(\mathrm{m})$ dan baris menunjukkan constraint yakni parameter datum translasi $\mathrm{x}, \mathrm{y}$, dan z. Pada matriks $D$, bernilai satu berarti origin (titik pusat/ titik nol) dari koordinat titik tersebut tidak mengalami translasi, sedangkan pada matriks $H$ pada semua titik dianggap memiliki kesalahan (mengalami translasi), sehingga diberi nilai satu pada setiap komponen titik.

Langkah selanjutnya, menentukan persamaan pengamatan jaring GPS. Persamaan yang digunakan adalah membuat persamaan baseline dengan seluruh kemungkinan baseline antar titik. Persamaan baseline yang merupakan fungsi nonlinier dilinierisasikan menjadi 3 vektor persamaan $\Delta x, \Delta y, \Delta z$ mengacu pada Gauss-Markov Model II (Mehrabi dan Voosoghi 2014).

$$
\left(\begin{array}{l}
\Delta x_{12} \\
\Delta y_{12} \\
\Delta z_{12}
\end{array}\right)=\left(\begin{array}{l}
x_{2}-x_{1} \\
y_{2}-y_{1} \\
z_{2}-z_{1}
\end{array}\right)
$$

2 dan 1 menunjukkan titik pengamatan. Dari persamaan akan didapatkan matriks desain atau matriks $A$ (Mehrabi dan Voosoghi 2014)

$$
A=\left[\begin{array}{llllll}
-1 & 0 & 0 & 1 & 0 & 0 \\
0 & -1 & 0 & 0 & 1 & 0 \\
0 & 0 & -1 & 0 & 0 & 1
\end{array}\right]
$$

Selanjutnya, membentuk matriks bobot pengamatan atau matriks $P$. Pada tahap perencanaan matriks $P$ yang dibuat menyesuaikan dari ketelitian alat. Matriks $P$ dapat dicari melalui persamaan berikut (Kuang 1991)

$$
\sigma_{s}^{2}=a^{2}+b^{2} \times S^{2}
$$

Nilai $S$ adalah panjang dari baseline, $a$ dan $b$ adalah nilai ketelitian alat yang digunakan (contoh 5 $\mathrm{mm}+0.5 \mathrm{ppm}$ ) (Lichten 1990). Pada tahap desain, bobot dari komponen $\Delta x, \Delta y, \Delta z$ adalah sama.

$$
P=\sigma_{0}^{2}\left(\operatorname{diag}\left(\sigma_{s}^{2}\right)\right)^{-1}
$$

$\sigma_{0}^{2}$ adalah faktor variansi apriori, pada tahap rencana nilainya adalah 1 sedangkan diag merupakan diagonal dari matriks. Langkah selanjutnya adalah menghitung nilai presisi awal dari jaring tersebut. Nilai presisi dapat diketahui melalui matriks variansi-kovariansi $(C x)$. rumus presisi secara umum adalah (Kuang 1996)

$$
C x=\sigma_{0}^{2} Q_{x}=\sigma_{0}^{2}\left[\left(A^{T} P A+D^{T} D\right)^{-1}-H^{T}\left(H D^{T} D H^{T}\right)^{-1} H\right]
$$

Jika persamaan datum telah dieliminasi pada persamaan pengamatan maka matriks variansi-kovariansi dapat dihitung dengan rumus (Kuang 1996):

$$
C_{X}=\sigma_{0}^{2}\left(A^{T} P A\right)^{-1}
$$

Perlu diketahui bahwa rumus presisi tersebut berbentuk nonlinear terhadap matriks $P$, 
sehingga persamaan (8) perlu dilinierisasikan mengikuti deret Taylor menjadi (Kuang 1996)

$$
C_{x}=C_{x}^{0}+\sum_{i=1}^{n} \frac{\partial C_{x}}{\partial P_{i}} \Delta P_{i}
$$

keterangan:

$$
\begin{aligned}
C x_{x}^{0}= & \sigma_{0}^{2}\left[\left(A^{T} P A+D^{T} D\right)^{-1}-H^{T}\left(H D^{T} D H^{T}\right)^{-1} H\right]_{x^{0} y^{0} z^{0} P^{0}} \\
\mathrm{i}= & (1, \ldots, \text { jumlah pengamatan }) \\
P^{0}= & \text { bobot awal } \\
\Delta p_{j}= & \text { besar perbaikan bobot yang dibutuhkan } \\
& \text { jaring untuk menjadi optimal }(\mathrm{j}: 1, \ldots, \mathrm{m}) .
\end{aligned}
$$

Langkah berikutnya adalah membuat matriks kriteria. Ukuran matriks kriteria sama dengan matriks presisi. Matriks kriteria berisi nilai ketelitian yang ingin dicapai pangkat dua $\left(\sigma_{c}^{2}\right)$ atau nilai variansi tiap titik sehingga (Kuang 1991)

$$
C_{c}=\operatorname{diag}\left(\sigma_{c}^{2}\right)
$$

Setelah semua matriks terdefinisi, dilanjutkan ke tahap kedua yakni proses optimasi. Proses optimasi yang dilakukan adalah optimasi presisi. Optimasi ini mengikuti objective function (OF) kriteria presisi yakni (Kuang 1991)

$$
\|G w-u\|=\min
$$

dengan kondisi penyelesaian

$$
w^{T} G^{T} G w-2 u^{T} G w+u^{T} u=\min
$$

mengacu pada syarat

$$
\begin{gathered}
G_{1} w-u_{1} \leq 0 \\
A_{00} w \leq b_{00}
\end{gathered}
$$

keterangan:

$$
\begin{aligned}
& G \quad=\left[\operatorname{vec}\left(\frac{\partial C_{x}}{\partial P_{1}}\right) \ldots \operatorname{vec}\left(\frac{\partial C_{x}}{\partial P_{i}}\right)\right] \\
& u=\operatorname{vec}\left(C_{c}\right)-\operatorname{vec}\left(C_{x}^{0}\right) \\
& w \quad=\left(\Delta p_{1} \ldots \Delta p_{i}\right)^{T} \\
& G_{1}=\left(I_{u} \Theta I_{u}\right)^{T} G \\
& u_{1}=\left(I_{u} \Theta I_{u}\right)^{T} u
\end{aligned}
$$

dimana "vec" menghasilkan vektor dengan menumpuk kolom matriks kuadrat satu dengan yang lainnya. Matriks I adalah matriks identitas dan $\Theta$ menunjukkan Khatri-Rao product
(Khameneh 2015). Proses penyelesaian Objective Function di atas sangat krusial untuk memperoleh nilai perubahan koordinat dan bobot optimasi. Kondisi penyelesaian tersebut dapat diselesaikan menggunakan quadratic programming (Kuang 1996).

Setelah melalui kedua tahapan di atas, nilai bobot pengamatan akhir didapatkan melalui penambahan nilai perbaikan bobot dengan nilai bobot pengamatan awal. Nilai presisi dapat dihitung kembali dengan adanya nilai perbaikan bobot pengamatan. Tahap ketiga yakni menentukan baseline yang digunakan. Baseline yang dihilangkan dari rencana dapat dilihat dari nilai optimasi bobotnya, yang mana nilai optimasinya bernilai negatif (Mehrabi dan Voosoghi 2014). Penentuan baseline yang dihilangkan juga dapat melalui nilai bobot akhir setelah optimasi. Nilai bobot yang kecil atau nol dapat dihapus dari rencana pengamatan (Kuang 1991). Pemilihan baseline ini dimaksudkan untuk mengurangi biaya pengamatan dengan tetap memperhatikan kualitas presisi jaringnya. Perbaikan nilai bobot ditampilkan dalam bentuk tabel untuk dianalisa.

Desain jaring dengan semua kemungkinan baseline dan desain jaring hasil optimasi ditampilkan dalam bentuk gambar dan diberi error ellipse per titik yang dapat dihitung melalui matriks variansi-kovariansi yakni matriks $C x$. Untuk mengetahui apakah jaring optimasi merupakan jaring yang optimal, maka selain kriteria presisi juga dihitung nilai kriteria reliabilitas dan biayanya. Kriteria reliabilitas berkaitan dengan nilai ukuran lebih atau redundant dari pengamatan untuk menghindari adanya kesalahan (Seemkooei 2001). Desain jaring baru dengan baseline pilihan juga dibuat untuk digunakan sebagai pembanding dengan jaring hasil optimasi. Desain jaring ini juga dihitung nilai presisi, reliabilitas, dan biayanya. Untuk menghitung nilai reliabilitas pada jaring dapat digunakan rumus berikut (Kuang 1996):

$$
R=I-A\left(A^{T} P A\right)^{-1} A^{T} P
$$

Nilai reliabilitas untuk setiap baseline didapatkan dari nilai pada diagonal matriks $R$. Untuk mengetahui kualitas baseline dari segi reliabilitas maka dapat mengacu pada nilai kritis reliabilitas berikut 
Tabel 1. Nilai Kritis Reliabilitas Jaring (Küreç dan Konak 2014)

\begin{tabular}{cc}
\hline Redundant & Tingkat Kontrol \\
\hline $0.00 \leq r_{i} \leq 0.01$ & Tidak Terkontrol \\
$0.01 \leq r_{i} \leq 0.10$ & Lemah \\
$0.10 \leq r_{i} \leq 0.30$ & Cukup \\
$0.30 \leq r_{i} \leq 1.00$ & Sangat Baik \\
\hline
\end{tabular}

Untuk melakukan perhitungan biaya desain jaring, Penelitian ini mengasumsikan bahwa jenis biaya yang harus dihitung adalah jumlah personel, alat, dan transportasi yang disesuaikan dengan lama pengamatan yang dibutuhkan. Karena pengamatan yang dilakukan tidak selalu dalam satu kali sesi, maka biaya juga dihitung mengacu pada jumlah sesi pengamatannya. Nominal dari jenis biaya ini dapat dilihat pada Tabel 2.

Tabel 2. Jenis dan Nominal Biaya (INKINDO 2017)

\begin{tabular}{cccc}
\hline No & Jenis Biaya & $\begin{array}{c}\text { Nominal } \\
\text { Biaya (Rp) }\end{array}$ & Keterangan \\
\hline 1 & Surveyor & $9,000,000$ & $\begin{array}{c}\text { Per Bulan } \\
\text { Termasuk O\&M } \\
\text { saja, Per Bulan } \\
\text { Termasuk O\&M, } \\
\text { Per Bulan }\end{array}$ \\
3 & Kendaraan Roda-4 & $14,000,000$ & Kendaraan Roda-2 \\
4 & $\begin{array}{c}\text { GPS Dual } \\
\text { Frequency }\end{array}$ & 500,000 & Per Hari, Satu set \\
\hline
\end{tabular}

Biaya yang ada pada Tabel 2 merupakan biaya pendekatan secara umum di wilayah Indonesia. Nominal tersebut dapat berubah-ubah sesuai dengan harga yang berlaku di wilayah pengamatan. Satuan dari nominal tersebut berbeda-beda. Nominal tersebut dapat dikonversi menjadi biaya harian dan jam melalui persamaan (INKINDO 2017):

$$
S B O H=\left(\frac{S B O B}{22}\right) \times 1.1
$$

dimana $\mathrm{SBOH}$ adalah satuan biaya orang hari dan SBOB adalah satuan biaya orang bulan. Pada penelitian ini, pengamatan deformasi yang dilakukan untuk satu sesi adalah 12 jam. Untuk perhitungan biaya, jumlah sesi ini diubah kedalam satuan hari dan apabila nilainya tidak bulat maka akan dibulatkan ke atas (misal 6.7 dibulatkan menjadi 7). Selain itu, nilai strength of figure (SOF) dari ketiga jaring dihitung untuk dilihat perbandingannya. Rumus untuk menghitung SOF adalah

$$
S O F=\frac{\operatorname{trace}\left(A^{T} A\right)^{-1}}{\text { jumlah parameter }}
$$

\section{HASIL DAN PEMBAHASAN}

Hasil dari optimasi adalah besar perubahan nilai bobot pada setiap baseline. Penentuan bobot awal berdasarkan ketelitian alat yang akan digunakan yakni $5 \mathrm{~mm}+0.5 \mathrm{ppm}$. Nilai bobot baseline sebelum dan sesudah optimasi dapat dilihat pada tabel berikut

Tabel 3. Nilai Bobot Pengamatan Sebelum dan Sesudah

\begin{tabular}{|c|c|c|c|c|}
\hline \multicolumn{2}{|c|}{ Pengamatan } & \multirow{2}{*}{$P_{\text {awal }}$} & \multirow{2}{*}{$P_{\text {baru }}$} & \multirow{2}{*}{$\begin{array}{c}\text { Perbaikan } \\
\text { Bobot }\end{array}$} \\
\hline Dari & $\mathrm{Ke}$ & & & \\
\hline 1 & 2 & 0.008 & 0.046 & 0.039 \\
\hline 1 & 3 & 0.009 & 0.046 & 0.037 \\
\hline 1 & 4 & 0.018 & 0.053 & 0.035 \\
\hline 1 & 5 & 0.028 & 0.062 & 0.035 \\
\hline 1 & 6 & 0.010 & 0.047 & 0.037 \\
\hline 1 & 7 & 0.014 & 0.049 & 0.035 \\
\hline 1 & 8 & 0.037 & 0.071 & 0.034 \\
\hline 1 & 9 & 0.029 & 0.064 & 0.035 \\
\hline 1 & 10 & 0.017 & 0.053 & 0.036 \\
\hline 1 & 11 & 0.020 & 0.056 & 0.036 \\
\hline 1 & 12 & 0.032 & 0.067 & 0.035 \\
\hline 1 & 13 & 0.027 & 0.061 & 0.035 \\
\hline 1 & 14 & 0.020 & 0.054 & 0.035 \\
\hline 1 & 15 & 0.028 & 0.063 & 0.035 \\
\hline 1 & 16 & 0.028 & 0.062 & 0.035 \\
\hline 1 & 17 & 0.013 & 0.049 & 0.036 \\
\hline 1 & 18 & 0.013 & 0.048 & 0.036 \\
\hline 1 & 19 & 0.025 & 0.060 & 0.035 \\
\hline 1 & 20 & 0.040 & 0.075 & 0.035 \\
\hline 1 & 21 & 0.040 & 0.075 & 0.035 \\
\hline 2 & 3 & 0.019 & 0.018 & -0.001 \\
\hline 2 & 4 & 0.017 & 0.017 & 0.000 \\
\hline 2 & 5 & 0.011 & 0.009 & -0.002 \\
\hline 2 & 6 & 0.032 & 0.037 & 0.005 \\
\hline 2 & 7 & 0.014 & 0.012 & -0.002 \\
\hline 2 & 8 & 0.010 & 0.007 & -0.003 \\
\hline 2 & 9 & 0.007 & 0.003 & -0.004 \\
\hline 2 & 10 & 0.021 & 0.021 & 0.000 \\
\hline 2 & 11 & 0.014 & 0.012 & -0.001 \\
\hline 2 & 12 & 0.008 & 0.005 & -0.003 \\
\hline 2 & 13 & 0.007 & 0.002 & -0.004 \\
\hline 2 & 14 & 0.009 & 0.005 & -0.004 \\
\hline 2 & 15 & 0.008 & 0.005 & -0.003 \\
\hline 2 & 16 & 0.010 & 0.007 & -0.003 \\
\hline 2 & 17 & 0.028 & 0.032 & 0.004 \\
\hline 2 & 18 & 0.021 & 0.022 & 0.001 \\
\hline
\end{tabular}
Optimasi 


\begin{tabular}{|c|c|c|c|c|c|c|c|c|c|}
\hline \multicolumn{2}{|c|}{ Pengamatan } & \multirow{2}{*}{$P_{\text {awal }}$} & \multirow{2}{*}{$P_{\text {baru }}$} & \multirow{2}{*}{$\begin{array}{c}\text { Perbaikan } \\
\text { Bobot }\end{array}$} & \multicolumn{2}{|c|}{ Pengamatan } & \multirow{2}{*}{$P_{\text {awal }}$} & \multirow{2}{*}{$P_{\text {baru }}$} & \multirow{2}{*}{$\begin{array}{c}\text { Perbaikan } \\
\text { Bobot }\end{array}$} \\
\hline Dari & $\mathrm{Ke}$ & & & & Dari & Ke & & & \\
\hline 2 & 19 & 0.015 & 0.014 & -0.001 & 5 & 14 & 0.032 & 0.023 & -0.009 \\
\hline 2 & 20 & 0.008 & 0.004 & -0.004 & 5 & 15 & 0.035 & 0.013 & -0.022 \\
\hline 2 & 21 & 0.008 & 0.004 & -0.004 & 5 & 16 & 0.021 & 0.022 & 0.002 \\
\hline 3 & 4 & 0.012 & 0.010 & -0.002 & 5 & 17 & 0.019 & 0.020 & 0.000 \\
\hline 3 & 5 & 0.017 & 0.017 & 0.000 & 5 & 18 & 0.024 & 0.021 & -0.003 \\
\hline 3 & 6 & 0.030 & 0.037 & 0.007 & 5 & 19 & 0.030 & 0.011 & -0.019 \\
\hline 3 & 7 & 0.032 & 0.038 & 0.007 & 5 & 20 & 0.028 & 0.022 & -0.006 \\
\hline 3 & 8 & 0.011 & 0.010 & -0.002 & 5 & 21 & 0.028 & 0.021 & -0.007 \\
\hline 3 & 9 & 0.011 & 0.009 & -0.002 & 6 & 7 & 0.022 & 0.026 & 0.003 \\
\hline 3 & 10 & 0.023 & 0.025 & 0.002 & 6 & 8 & 0.012 & 0.011 & -0.001 \\
\hline 3 & 11 & 0.024 & 0.024 & 0.001 & 6 & 9 & 0.010 & 0.006 & -0.003 \\
\hline 3 & 12 & 0.008 & 0.003 & -0.005 & 6 & 10 & 0.028 & 0.029 & 0.001 \\
\hline 3 & 13 & 0.011 & 0.009 & -0.003 & 6 & 11 & 0.021 & 0.022 & 0.001 \\
\hline 3 & 14 & 0.018 & 0.019 & 0.001 & 6 & 12 & 0.009 & 0.006 & -0.004 \\
\hline 3 & 15 & 0.014 & 0.014 & -0.001 & 6 & 13 & 0.009 & 0.006 & -0.004 \\
\hline 3 & 16 & 0.009 & 0.004 & -0.004 & 6 & 14 & 0.013 & 0.013 & -0.001 \\
\hline 3 & 17 & 0.018 & 0.020 & 0.001 & 6 & 15 & 0.012 & 0.010 & -0.001 \\
\hline 3 & 18 & 0.035 & 0.041 & 0.007 & 6 & 16 & 0.011 & 0.008 & -0.003 \\
\hline 3 & 19 & 0.015 & 0.015 & 0.000 & 6 & 17 & 0.028 & 0.034 & 0.006 \\
\hline 3 & 20 & 0.009 & 0.006 & -0.003 & 6 & 18 & 0.033 & 0.039 & 0.006 \\
\hline 3 & 21 & 0.009 & 0.006 & -0.003 & 6 & 19 & 0.018 & 0.019 & 0.000 \\
\hline 4 & 5 & 0.020 & 0.021 & 0.001 & 6 & 20 & 0.010 & 0.006 & -0.003 \\
\hline 4 & 6 & 0.017 & 0.019 & 0.001 & 6 & 21 & 0.010 & 0.007 & -0.003 \\
\hline 4 & 7 & 0.014 & 0.013 & 0.000 & 7 & 8 & 0.016 & 0.018 & 0.002 \\
\hline 4 & 8 & 0.024 & 0.024 & 0.000 & 7 & 9 & 0.018 & 0.021 & 0.003 \\
\hline 4 & 9 & 0.013 & 0.012 & 0.000 & 7 & 10 & 0.026 & 0.027 & 0.001 \\
\hline 4 & 10 & 0.027 & 0.028 & 0.000 & 7 & 11 & 0.034 & 0.027 & -0.007 \\
\hline 4 & 11 & 0.019 & 0.021 & 0.002 & 7 & 12 & 0.011 & 0.008 & -0.002 \\
\hline 4 & 12 & 0.024 & 0.029 & 0.005 & 7 & 13 & 0.018 & 0.021 & 0.003 \\
\hline 4 & 13 & 0.012 & 0.010 & -0.001 & 7 & 14 & 0.030 & 0.034 & 0.004 \\
\hline 4 & 14 & 0.012 & 0.012 & -0.001 & 7 & 15 & 0.023 & 0.025 & 0.002 \\
\hline 4 & 15 & 0.014 & 0.016 & 0.001 & 7 & 16 & 0.011 & 0.009 & -0.002 \\
\hline 4 & 16 & 0.029 & 0.035 & 0.006 & 7 & 17 & 0.018 & 0.019 & 0.002 \\
\hline 4 & 17 & 0.032 & 0.038 & 0.006 & 7 & 18 & 0.033 & 0.037 & 0.004 \\
\hline 4 & 18 & 0.018 & 0.020 & 0.002 & 7 & 19 & 0.019 & 0.021 & 0.002 \\
\hline 4 & 19 & 0.034 & 0.028 & -0.006 & 7 & 20 & 0.014 & 0.015 & 0.001 \\
\hline 4 & 20 & 0.018 & 0.021 & 0.003 & 7 & 21 & 0.014 & 0.015 & 0.001 \\
\hline 4 & 21 & 0.018 & 0.021 & 0.003 & 8 & 9 & 0.027 & 0.027 & 0.000 \\
\hline 5 & 6 & 0.016 & 0.016 & 0.000 & 8 & 10 & 0.023 & 0.020 & -0.003 \\
\hline 5 & 7 & 0.026 & 0.023 & -0.004 & 8 & 11 & 0.024 & 0.020 & -0.004 \\
\hline 5 & 8 & 0.032 & 0.009 & -0.022 & 8 & 12 & 0.033 & 0.029 & -0.004 \\
\hline 5 & 9 & 0.030 & 0.024 & -0.006 & 8 & 13 & 0.024 & 0.027 & 0.003 \\
\hline 5 & 10 & 0.029 & 0.014 & -0.014 & 8 & 14 & 0.021 & 0.024 & 0.004 \\
\hline 5 & 11 & 0.036 & 0.003 & -0.033 & 8 & 15 & 0.028 & 0.023 & -0.004 \\
\hline 5 & 12 & 0.021 & 0.023 & 0.002 & 8 & 16 & 0.032 & 0.028 & -0.003 \\
\hline 5 & 13 & 0.029 & 0.026 & -0.003 & 8 & 17 & 0.018 & 0.019 & 0.001 \\
\hline
\end{tabular}




\begin{tabular}{|c|c|c|c|c|}
\hline \multicolumn{2}{|c|}{ Pengamatan } & \multirow{2}{*}{$P_{\text {awal }}$} & \multirow{2}{*}{$P_{\text {baru }}$} & \multirow{2}{*}{$\begin{array}{c}\text { Perbaikar } \\
\text { Bobot }\end{array}$} \\
\hline Dari & $\mathrm{Ke}$ & & & \\
\hline 8 & 18 & 0.016 & 0.018 & 0.002 \\
\hline 8 & 19 & 0.032 & 0.014 & -0.019 \\
\hline 8 & 20 & 0.037 & 0.020 & -0.016 \\
\hline 8 & 21 & 0.037 & 0.020 & -0.017 \\
\hline 9 & 10 & 0.016 & 0.019 & 0.003 \\
\hline 9 & 11 & 0.024 & 0.026 & 0.002 \\
\hline 9 & 12 & 0.018 & 0.022 & 0.004 \\
\hline 9 & 13 & 0.040 & 0.043 & 0.003 \\
\hline 9 & 14 & 0.030 & 0.035 & 0.005 \\
\hline 9 & 15 & 0.038 & 0.033 & -0.005 \\
\hline 9 & 16 & 0.016 & 0.019 & 0.003 \\
\hline 9 & 17 & 0.011 & 0.010 & -0.002 \\
\hline 9 & 18 & 0.014 & 0.015 & 0.001 \\
\hline 9 & 19 & 0.019 & 0.023 & 0.004 \\
\hline 9 & 20 & 0.029 & 0.031 & 0.002 \\
\hline 9 & 21 & 0.030 & 0.031 & 0.001 \\
\hline 10 & 11 & 0.032 & 0.017 & -0.015 \\
\hline 10 & 12 & 0.017 & 0.019 & 0.002 \\
\hline 10 & 13 & 0.016 & 0.018 & 0.003 \\
\hline 10 & 14 & 0.020 & 0.023 & 0.003 \\
\hline 10 & 15 & 0.020 & 0.022 & 0.002 \\
\hline 10 & 16 & 0.019 & 0.021 & 0.002 \\
\hline 10 & 17 & 0.033 & 0.031 & -0.003 \\
\hline 10 & 18 & 0.033 & 0.028 & -0.005 \\
\hline 10 & 19 & 0.033 & 0.016 & -0.017 \\
\hline 10 & 20 & 0.017 & 0.020 & 0.003 \\
\hline 10 & 21 & 0.017 & 0.020 & 0.003 \\
\hline 11 & 12 & 0.016 & 0.019 & 0.003 \\
\hline 11 & 13 & 0.024 & 0.026 & 0.003 \\
\hline 11 & 14 & 0.032 & 0.027 & -0.006 \\
\hline 11 & 15 & 0.030 & 0.022 & -0.008 \\
\hline 11 & 16 & 0.016 & 0.019 & 0.002 \\
\hline 11 & 17 & 0.021 & 0.022 & 0.001 \\
\hline 11 & 18 & 0.031 & 0.025 & -0.006 \\
\hline 11 & 19 & 0.027 & 0.019 & -0.009 \\
\hline 11 & 20 & 0.020 & 0.023 & 0.003 \\
\hline 11 & 21 & 0.020 & 0.023 & 0.003 \\
\hline 12 & 13 & 0.017 & 0.019 & 0.003 \\
\hline 12 & 14 & 0.013 & 0.014 & 0.000 \\
\hline 12 & 15 & 0.018 & 0.022 & 0.004 \\
\hline 12 & 16 & 0.038 & 0.046 & 0.008 \\
\hline 12 & 17 & 0.015 & 0.016 & 0.001 \\
\hline 12 & 18 & 0.011 & 0.010 & -0.002 \\
\hline 12 & 19 & 0.026 & 0.027 & 0.001 \\
\hline 12 & 20 & 0.032 & 0.035 & 0.003 \\
\hline 12 & 21 & 0.032 & 0.035 & 0.003 \\
\hline
\end{tabular}

\begin{tabular}{|c|c|c|c|c|}
\hline \multicolumn{2}{|c|}{ Pengamatan } & \multirow{2}{*}{$P_{\text {awal }}$} & \multirow{2}{*}{$P_{\text {baru }}$} & \multirow{2}{*}{$\begin{array}{c}\text { Perbaikan } \\
\text { Bobot }\end{array}$} \\
\hline Dari & Ke & & & \\
\hline 13 & 14 & 0.032 & 0.037 & 0.005 \\
\hline 13 & 15 & 0.038 & 0.035 & -0.002 \\
\hline 13 & 16 & 0.015 & 0.016 & 0.001 \\
\hline 13 & 17 & 0.011 & 0.008 & -0.002 \\
\hline 13 & 18 & 0.014 & 0.014 & 0.001 \\
\hline 13 & 19 & 0.018 & 0.022 & 0.004 \\
\hline 13 & 20 & 0.027 & 0.031 & 0.004 \\
\hline 13 & 21 & 0.027 & 0.031 & 0.004 \\
\hline 14 & 15 & 0.035 & 0.032 & -0.003 \\
\hline 14 & 16 & 0.013 & 0.012 & 0.000 \\
\hline 14 & 17 & 0.013 & 0.013 & 0.000 \\
\hline 14 & 18 & 0.021 & 0.024 & 0.003 \\
\hline 14 & 19 & 0.019 & 0.022 & 0.004 \\
\hline 14 & 20 & 0.020 & 0.024 & 0.005 \\
\hline 14 & 21 & 0.020 & 0.025 & 0.005 \\
\hline 15 & 16 & 0.017 & 0.020 & 0.003 \\
\hline 15 & 17 & 0.013 & 0.014 & 0.000 \\
\hline 15 & 18 & 0.018 & 0.020 & 0.002 \\
\hline 15 & 19 & 0.022 & 0.023 & 0.002 \\
\hline 15 & 20 & 0.028 & 0.028 & 0.000 \\
\hline 15 & 21 & 0.028 & 0.028 & 0.000 \\
\hline 16 & 17 & 0.018 & 0.021 & 0.002 \\
\hline 16 & 18 & 0.012 & 0.012 & -0.001 \\
\hline 16 & 19 & 0.030 & 0.028 & -0.002 \\
\hline 16 & 20 & 0.028 & 0.032 & 0.004 \\
\hline 16 & 21 & 0.027 & 0.031 & 0.004 \\
\hline 17 & 18 & 0.026 & 0.030 & 0.004 \\
\hline 17 & 19 & 0.029 & 0.026 & -0.003 \\
\hline 17 & 20 & 0.013 & 0.014 & 0.000 \\
\hline 17 & 21 & 0.013 & 0.014 & 0.001 \\
\hline 18 & 19 & 0.022 & 0.022 & 0.000 \\
\hline 18 & 20 & 0.013 & 0.013 & 0.000 \\
\hline 18 & 21 & 0.013 & 0.013 & 0.001 \\
\hline 19 & 20 & 0.025 & 0.025 & 0.000 \\
\hline 19 & 21 & 0.025 & 0.024 & 0.000 \\
\hline 20 & 21 & 0.040 & 0.029 & -0.011 \\
\hline
\end{tabular}

Dari Tabel 3 dapat dilihat bahwa setelah melalui proses optimasi, dari total 210 baseline, bobot dari beberapa baseline pengamatan mengalami perubahan. Peningkatan terbesar terdapat pada pengamatan 1-2 dengan nilai sebesar 0.039 sedangkan penurunan bobot terkecil terdapat pada pengamatan 5-11 dengan nilai sebesar -0.033. Jika dikaitkan dengan rumus perhitungan bobot, bobot pengamatan yang memiliki nilai yang tinggi/besar memiliki jarak baseline yang pendek 
sehingga kesalahan yang terjadi pada baseline tersebut kecil. Oleh karena itu, baseline tersebut harus digunakan pada rencana pengamatan. Untuk mendapatkan desain jaring yang optimal, Baseline dengan bobot yang relatif kecil akan dihilangkan dari rencana pengamatan.

Tabel 4. Bobot Hasil Seleksi

\begin{tabular}{|c|c|c|}
\hline \multicolumn{2}{|c|}{ Pengamatan } & \multirow{2}{*}{$P_{\text {baru }}$} \\
\hline Dari & Dari & \\
\hline 1 & 2 & 0.046 \\
\hline 1 & 3 & 0.046 \\
\hline 1 & 4 & 0.053 \\
\hline
\end{tabular}

1

1

1

1

1

1

1

1

1

1

1

1

1

1

1

1

2

2

2

2

3

3

3

3

3

4

4

4

4

4

4

4

4

4
0.062

0.047

0.049

0.071

0.064

0.053

0.056

0.067

0.061

0.054

0.063

0.062

0.049

0.048

0.060

0.075

0.075

0.037

0.021

0.032

0.022

0.037

0.038

0.025

0.024

0.041

0.021

0.024

0.028

0.021

0.029

0.035

0.038

0.028

0.021

\begin{tabular}{|c|c|c|}
\hline \multicolumn{2}{|c|}{ Pengamatan } & \multirow{2}{*}{$P_{\text {baru }}$} \\
\hline Dari & Dari & \\
\hline 4 & 21 & 0.021 \\
\hline 5 & 7 & 0.023 \\
\hline 5 & 9 & 0.024 \\
\hline 5 & 12 & 0.023 \\
\hline 5 & 13 & 0.026 \\
\hline 5 & 14 & 0.023 \\
\hline 5 & 16 & 0.022 \\
\hline 5 & 18 & 0.021 \\
\hline 5 & 20 & 0.022 \\
\hline 5 & 21 & 0.021 \\
\hline 6 & 7 & 0.026 \\
\hline 6 & 10 & 0.029 \\
\hline 6 & 11 & 0.022 \\
\hline 6 & 17 & 0.034 \\
\hline 6 & 18 & 0.039 \\
\hline 7 & 9 & 0.021 \\
\hline 7 & 10 & 0.027 \\
\hline 7 & 11 & 0.027 \\
\hline 7 & 13 & 0.021 \\
\hline 7 & 14 & 0.034 \\
\hline 7 & 15 & 0.025 \\
\hline 7 & 18 & 0.037 \\
\hline 7 & 19 & 0.021 \\
\hline 8 & 9 & 0.027 \\
\hline 8 & 11 & 0.020 \\
\hline 8 & 12 & 0.029 \\
\hline 8 & 13 & 0.027 \\
\hline 8 & 14 & 0.024 \\
\hline 8 & 15 & 0.023 \\
\hline 8 & 16 & 0.028 \\
\hline 8 & 20 & 0.020 \\
\hline 9 & 11 & 0.026 \\
\hline 9 & 12 & 0.022 \\
\hline 9 & 13 & 0.043 \\
\hline 9 & 14 & 0.035 \\
\hline 9 & 15 & 0.033 \\
\hline 9 & 19 & 0.023 \\
\hline 9 & 20 & 0.031 \\
\hline 9 & 21 & 0.031 \\
\hline 10 & 14 & 0.023 \\
\hline 10 & 15 & 0.022 \\
\hline 10 & 16 & 0.021 \\
\hline 10 & 17 & 0.031 \\
\hline 10 & 18 & 0.028 \\
\hline 10 & 20 & 0.020 \\
\hline 10 & 21 & 0.020 \\
\hline
\end{tabular}




\begin{tabular}{|c|c|c|}
\hline \multicolumn{2}{|c|}{ Pengamatan } & \multirow{2}{*}{$P_{\text {baru }}$} \\
\hline Dari & Dari & \\
\hline 11 & 13 & 0.026 \\
\hline 11 & 14 & 0.027 \\
\hline 11 & 15 & 0.022 \\
\hline 11 & 17 & 0.022 \\
\hline 11 & 18 & 0.025 \\
\hline 11 & 20 & 0.023 \\
\hline 11 & 21 & 0.023 \\
\hline 12 & 15 & 0.022 \\
\hline 12 & 16 & 0.046 \\
\hline 12 & 19 & 0.027 \\
\hline 12 & 20 & 0.035 \\
\hline 12 & 21 & 0.035 \\
\hline 13 & 14 & 0.037 \\
\hline 13 & 15 & 0.035 \\
\hline 13 & 19 & 0.022 \\
\hline 13 & 20 & 0.031 \\
\hline 13 & 21 & 0.031 \\
\hline 14 & 15 & 0.032 \\
\hline 14 & 18 & 0.024 \\
\hline 14 & 19 & 0.022 \\
\hline 14 & 20 & 0.024 \\
\hline 14 & 21 & 0.025 \\
\hline 15 & 19 & 0.023 \\
\hline 15 & 20 & 0.028 \\
\hline 15 & 21 & 0.028 \\
\hline 16 & 17 & 0.021 \\
\hline 16 & 19 & 0.028 \\
\hline 16 & 20 & 0.032 \\
\hline 16 & 21 & 0.031 \\
\hline 17 & 18 & 0.030 \\
\hline 17 & 19 & 0.026 \\
\hline 18 & 19 & 0.022 \\
\hline 19 & 20 & 0.025 \\
\hline 19 & 21 & 0.024 \\
\hline 20 & 21 & 0.029 \\
\hline
\end{tabular}

Seleksi baseline dilakukan dengan menghilangkan baseline dengan nilai bobot yang lebih kecil dari 0.02. Dari total 210 baseline yang ada, sebanyak 91 baseline memiliki nilai bobot yang lebih kecil dari nilai kriteria 0.02. Baseline tersebut dapat dihilangkan dari rencana pengamatan. Baseline yang tersisa, sebanyak 119 baseline digunakan untuk membentuk desain jaring hasil optimasi. Nilai presisi desain jaring dengan semua baseline dan hasil optimasi selanjutnya dapat dihitung dengan menggunakan nilai bobot yang terdapat pada Tabel 3 dan 4. Desain jaring dengan semua baseline diberi nama desain jaring maksimum sedangkan desain jaring hasil optimasi diberi nama desain jaring optimasi.

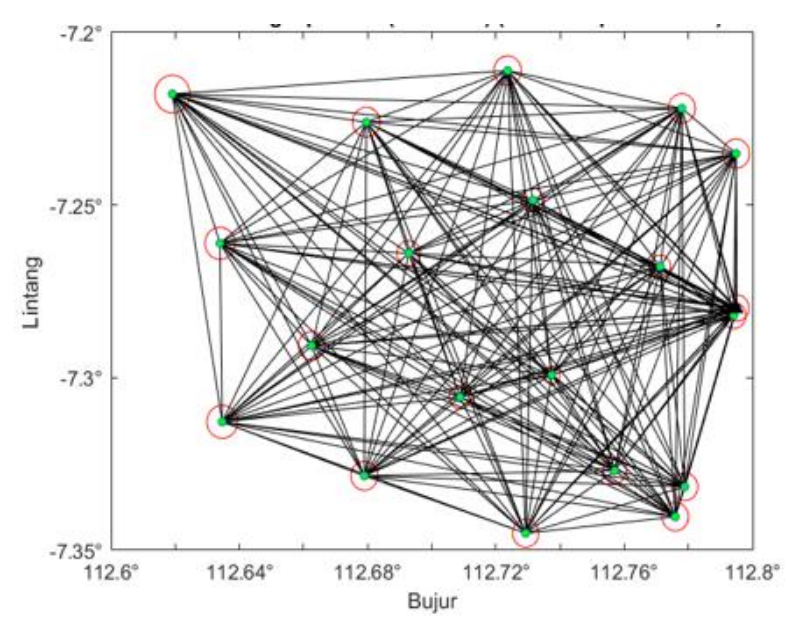

Gambar 2. Desain Jaring Maksimum

Desain jaring maksimum memiliki nilai SOF sebesar 0.095. Secara visual, besar dari error ellipse pada setiap titik memiliki ukuran yang kecil. Error ellipse yang kecil ini mengindikasikan bahwa titik tersebut memiliki nilai kesalahan yang kecil. Besar kesalahan pada setiap titik dapat diketahui dari nilai presisi jaring tersebut. Nilai presisi jaring maksimum dapat dilihat pada tabel berikut:

Tabel 5. Presisi Desain Jaring Maksimum

\begin{tabular}{cccc}
\hline \multirow{2}{*}{ Titik } & \multicolumn{3}{c}{ Presisi } \\
\cline { 2 - 4 } & $\sigma_{x}(\mathrm{~mm})$ & $\sigma_{y}(\mathrm{~mm})$ & $\sigma_{z}(\mathrm{~mm})$ \\
\hline \hline 1 & 0.000 & 0.000 & 0.000 \\
2 & 1.863 & 1.863 & 1.863 \\
3 & 1.433 & 1.433 & 1.433 \\
4 & 1.137 & 1.137 & 1.137 \\
5 & 0.405 & 0.405 & 0.405 \\
6 & 1.355 & 1.355 & 1.355 \\
7 & 1.097 & 1.097 & 1.097 \\
8 & 0.669 & 0.669 & 0.669 \\
9 & 1.002 & 1.002 & 1.002 \\
10 & 0.834 & 0.834 & 0.834 \\
11 & 0.732 & 0.732 & 0.732 \\
12 & 1.111 & 1.111 & 1.111 \\
13 & 1.067 & 1.067 & 1.067 \\
14 & 1.030 & 1.030 & 1.030 \\
15 & 0.851 & 0.851 & 0.851 \\
16 & 1.119 & 1.119 & 1.119 \\
17 & 1.149 & 1.149 & 1.149 \\
18 & 1.046 & 1.046 & 1.046 \\
& & &
\end{tabular}




\begin{tabular}{llll}
19 & 0.750 & 0.750 & 0.750 \\
20 & 0.894 & 0.894 & 0.894 \\
21 & 0.883 & 0.883 & 0.883 \\
\hline
\end{tabular}

Nilai presisi maksimum pada desain jaring maksimum terletak pada titik 4 dengan nilai standar deviasi sebesar $0.405 \mathrm{~mm}$ sedangkan presisi minimum terletak pada titik 2 dengan nilai sebesar $1.863 \mathrm{~mm}$.

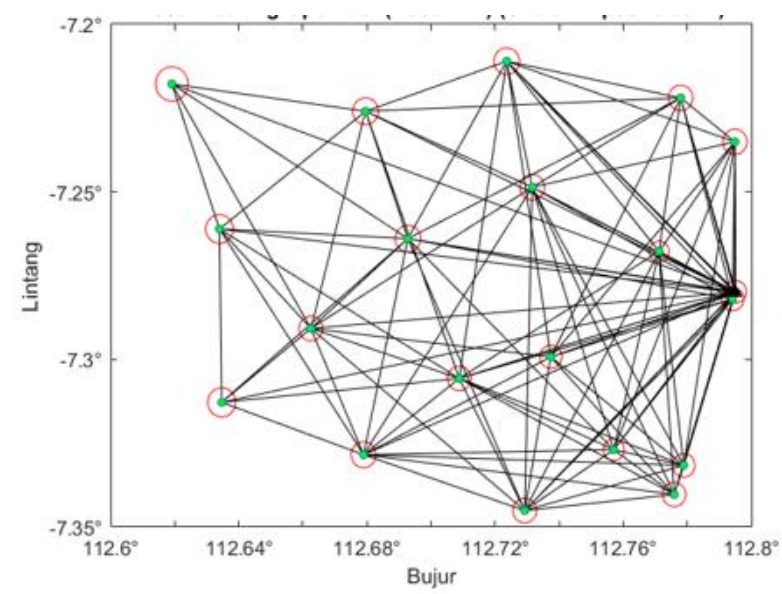

Gambar 3. Desain Jaring Optimasi

Desain jaring optimasi memiliki nilai SOF sebesar 0.145. Secara visual, besar dari error ellipse pada setiap titik memiliki ukuran yang kecil. Error ellipse yang kecil ini mengindikasikan bahwa titik tersebut memiliki nilai kesalahan yang kecil. Besar kesalahan pada setiap titik dapat diketahui dari nilai presisi jaring tersebut. Nilai presisi jaring optimasi dapat dilihat pada tabel berikut:

Tabel 5. Presisi Desain Jaring Optimasi

\begin{tabular}{cccc}
\hline \multirow{2}{*}{ Titik } & \multicolumn{3}{c}{ Presisi } \\
\cline { 2 - 4 } & $\sigma_{x}(\mathrm{~mm})$ & $\sigma_{y}(\mathrm{~mm})$ & $\sigma_{z}(\mathrm{~mm})$ \\
\hline 1 & 0.000 & 0.000 & 0.000 \\
2 & 1.619 & 1.619 & 1.619 \\
3 & 1.177 & 1.177 & 1.177 \\
4 & 0.986 & 0.986 & 0.986 \\
5 & 0.737 & 0.737 & 0.737 \\
6 & 1.145 & 1.145 & 1.145 \\
7 & 0.940 & 0.940 & 0.940 \\
8 & 0.605 & 0.605 & 0.605 \\
9 & 0.769 & 0.769 & 0.769 \\
10 & 0.994 & 0.994 & 0.994 \\
11 & 0.828 & 0.828 & 0.828 \\
12 & 0.886 & 0.886 & 0.886 \\
13 & 0.819 & 0.819 & 0.819 \\
14 & 0.852 & 0.852 & 0.852
\end{tabular}

\begin{tabular}{cccc}
\hline \multirow{2}{*}{ Titik } & \multicolumn{3}{c}{ Presisi } \\
\cline { 2 - 4 } & $\sigma_{x}(\mathrm{~mm})$ & $\sigma_{y}(\mathrm{~mm})$ & $\sigma_{z}(\mathrm{~mm})$ \\
\hline \hline 15 & 0.652 & 0.652 & 0.652 \\
16 & 0.887 & 0.887 & 0.887 \\
17 & 0.992 & 0.992 & 0.992 \\
\hline 18 & 0.857 & 0.857 & 0.857 \\
19 & 0.915 & 0.915 & 0.915 \\
20 & 0.689 & 0.689 & 0.689 \\
21 & 0.760 & 0.760 & 0.760 \\
\hline
\end{tabular}

Nilai presisi maksimum pada desain jaring optimasi terletak pada titik 8 dengan nilai standar deviasi sebesar $0.605 \mathrm{~mm}$ sedangkan presisi minimum terletak pada titik 2 dengan nilai standar deviasi sebesar $1.619 \mathrm{~mm}$. Jika dibandingkan dengan desain jaring maksimum, nilai presisi desain jaring optimasi memiliki nilai presisi yang lebih baik dibandingkan dengan desain jaring maksimum. Meskipun nilai presisi maksimum desain jaring optimasi tidak lebih baik daripada desain jaring maksimum, tetapi secara keseluruhan pada setiap titik, nilai presisi pada desain jaring optimasi lebih baik. Dari 21 titik pengamatan, terdapat 16 titik megalami kenaikan nilai presisi. Berdasarkan hal tersebut dapat dikatakan desain jaring optimasi merupakan desain jaring yang optimal. Kemudian, untuk membuktikan desain jaring optimasi merupakan jaring yang optimal maka dibuat desain baru sebagai pembanding. Adapun bentuk dari desain baru ini seperti pada gambar berikut

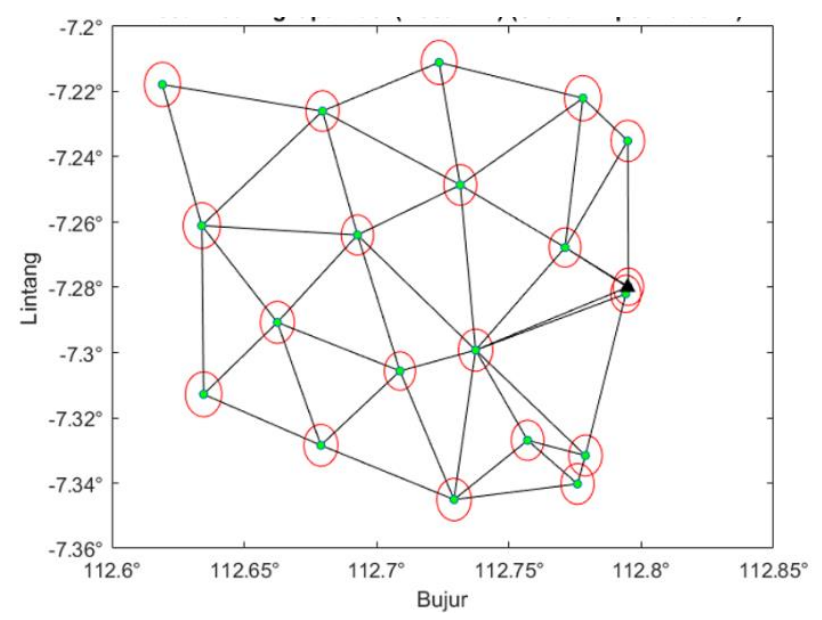

Gambar 4. Desain Jaring Baru

Desain jaring optimasi memiliki nilai SOF sebesar 0.704. Presisi desain jaring ini dihitung untuk dapat dibandingkan dengan desain jaring optimasi. Nilai presisi jaring baru dapat dilihat pada tabel berikut: 
Tabel 6. Presisi Desain Jaring Baru

\begin{tabular}{|c|c|c|c|}
\hline \multirow{2}{*}{ Titik } & \multicolumn{3}{|c|}{ Presisi } \\
\hline & $\sigma_{x}(\mathrm{~mm})$ & $\sigma_{y}(\mathrm{~mm})$ & $\sigma_{z}(\mathrm{~mm})$ \\
\hline 1 & 0.000 & 0.000 & 0.000 \\
\hline 2 & 2.733 & 2.733 & 2.733 \\
\hline 3 & 3.306 & 3.306 & 3.306 \\
\hline 4 & 2.876 & 2.876 & 2.876 \\
\hline 5 & 1.248 & 1.248 & 1.248 \\
\hline 6 & 3.080 & 3.080 & 3.080 \\
\hline 7 & 3.470 & 3.470 & 3.470 \\
\hline 8 & 1.090 & 1.090 & 1.090 \\
\hline 9 & 2.010 & 2.010 & 2.010 \\
\hline 10 & 3.527 & 3.527 & 3.527 \\
\hline 11 & 4.744 & 4.744 & 4.744 \\
\hline 12 & 1.704 & 1.704 & 1.704 \\
\hline 13 & 2.847 & 2.847 & 2.847 \\
\hline 14 & 2.790 & 2.790 & 2.790 \\
\hline 15 & 3.332 & 3.332 & 3.332 \\
\hline 16 & 2.072 & 2.072 & 2.072 \\
\hline 17 & 2.981 & 2.981 & 2.981 \\
\hline 18 & 3.536 & 3.536 & 3.536 \\
\hline 19 & 3.295 & 3.295 & 3.295 \\
\hline 20 & 1.240 & 1.240 & 1.240 \\
\hline 21 & 1.435 & 1.435 & 1.435 \\
\hline
\end{tabular}

Nilai presisi maksimum pada desain jaring optimasi terletak pada titik 8 dengan nilai standar deviasi sebesar $1.090 \mathrm{~mm}$ sedangkan presisi minimum terletak pada titik 11 dengan nilai standar deviasi sebesar $4.744 \mathrm{~mm}$. Jika dibandingkan dengan nilai presisi desain jaring optimasi, nilai presisi desain jaring baru memiliki nilai yang kurang baik. Dengan hasil ini, maka didapatkan desain jaring optimasi sebagai desain jaring yang optimal. Selain dari segi presisi, jaring optimal juga harus memiliki nilai reliabilitas yang baik.

Tabel 7. Perbandingan Reliabilitas Desain Jaring

\begin{tabular}{cccc}
\hline Desain & $\begin{array}{c}\text { Reliabilitas } \\
\text { Minimum }\end{array}$ & $\begin{array}{c}\text { Reliabilitas } \\
\text { Maksimum }\end{array}$ & $\begin{array}{c}\text { Reliabilitas } \\
\text { Rata-Rata }\end{array}$ \\
\hline $\begin{array}{c}\text { Desain } \\
\text { Jaring }\end{array}$ & 0.795 & 0.987 & 0.905 \\
$\begin{array}{c}\text { Maksimum } \\
\text { Desain } \\
\text { Jaring } \\
\text { Optimasi } \\
\text { Desain }\end{array}$ & 0.632 & 0.928 & 0.832 \\
Jaring Baru & 0.266 & 0.875 & 0.574 \\
\hline
\end{tabular}

Nilai reliabilitas berada pada rentang 0 sampai 1. Dari Tabel 7, desain jaring maksimum memiliki nilai yang tertinggi dengan nilai rata-rata sebesar 0.905. nilai reliabilitas yang besar menandakan bahwa jaring tersebut dapat menghindari kesalahan dengan baik. Desain jaring optimasi, yang merupakan desain jaring yang optimal dari segi presisi, memiliki nilai yang baik juga sehingga dari segi reliabilitas, desain jaring ini dianggap baik. Terakhir, dilakukan perbandingan berdasarkan total biaya yang dibutuhkan untuk merealisasi desain jaring.

Tabel 8. Total Biaya Desain Jaring

\begin{tabular}{cc}
\hline Desain & Total Biaya (Rp) \\
\hline Desain Jaring Maksimum & $113,062,500$ \\
Desain Jaring Optimasi & $62,812,500$ \\
Desain Jaring Baru & $25,125,000$ \\
\hline
\end{tabular}

Berdasarkan perhitungan biaya, desain jaring baru memiliki biaya realisasi yang paling kecil diantara ketiga desain jaring. Desain jaring optimasi berada di urutan berikutnya dengan perbedaan biaya mencapai $3 x$ lipat. Mengacu pada presisi dan reliabilitas desain jaring, maka didapatkan desain jaring optimasi sebagai desain jaring yang optimal dari segi presisi, reliabilitas, dan biaya. Jika diasumsikan biaya desain jaring maksimum adalah biaya maksimum, desain jaring optimasi dapat menghemat biaya sebesar $44 \%$.

\section{KESIMPULAN}

Berdasarkan hasil pengolahan dan analisis, desain optimal dari segi presisi, reliabilitas, dan biaya ditunjukkan pada desain jaring optimasi. Desain ini merupakan desain hasil eliminasi beberapa pengamatan yang tidak berdampak signifikan pada presisi jaring. Nilai presisi maksimum dari desain jaring optimasi terletak pada titik 8 sebesar 0.605 $\mathrm{mm}$ dan presisi minimum pada titik 2 sebesar 1.619 $\mathrm{mm}$. Kekuatan geometri desain jaring optimasi sebesar 0.145 dengan biaya realisasi desain ini mencapai 62,812,500 Rupiah.

\section{UCAPAN TERIMA KASIH}

Penulis YAS mengucapkan terima kasih kepada Ibu Ira Mutiara Anjasmara S.T., M.Phil Ph.D sebagai dosen pembimbing sekaligus penyedia data yang telah membantu terlaksananya penelitian ini, 
terutama perihal ketersediaan data yang diperlukan serta bimbingan selama proses pengolahan data.

\section{DAFTAR PUSTAKA}

Al zubaidy, Riyadh Z, Hussen A. Mahdi, dan Hind Sabah Hanooka. 2012. Optimized Zero and First Order Design of Micro Geodetic Networks. Journal of Engineering, Vol. 18 No. 12.

Ikatan Nasional Konsultan Indonesia. 2017. Pedoman Standar Minimal. Jakarta: Dewan Pengurus Nasional.

Kaplan, M. O., dan Ayan, T. 2004. The Effects of Geodetic Configuration of the Network in Deformation Analysis. FIG Working Week, Vol. 29 No. 6:1-15.

Khameneh, M. 2015. On Optimisation and Design of Geodetic Networks.: Royal Institute of Technology.

Khameneh, Lars E. Sjöberg, dan Anna B. O. Jensen. 2016. Optimization of GNSS Deformation Monitoring Networks by Considering Baseline Correlations. New Zealand: FIG Working Week 2016.

Kuang, Shan-long. 1991. Optimization and Design of Deformation Monitoring Schemes. Department of Surveying Engineering Technical Report No. 157. University of New Brunswick, Fredericton, New Brunswick, Kanada, 179 pp.
Kuang, Shanlong. Geodetic Network Analysis and Optimal Design : Concepts and Applications. Michigan : Ann Arbor Press .Inc (1996).

Küreç, P. dan H. Konak. 2014. A Priori Sensitivity Analysis for Densification GPS Networks and Their Capacities of Crustal Deformation Monitoring: A Real GPS Network Application. Natural Hazards and Earth System Science, Vol 14.

Lichten, Stephen M. 1990. High Accuracy Global Positioning System Orbit Determination: Progress and Prospects. California Institute of Technology: Amerika Serikat.

Mehrabi dan H, B. Voosoghi. 2014. Optimal Observational Planning of Local GPS Networks: assessing an analitis method. Journal of geodetic science Vol.4 :87-97.

Seemkooei, A. A. 2001. Comparison of Reliability and Geometrical Strength Criteria in Geodetic Networks. Journal of Geodesy, Vol. 75 No. 4:227-233.

Standar Nasional Indonesia. 2002. Jaring Kontrol Horizontal. Jakarta. 